\title{
Innovation Culture and Process in Mediating Human Capital Supply Chain on Firm Performance
}

\author{
Muafi MUAFI ${ }^{1}$, Yuni SISWANTI ${ }^{2}$, Awan Kostrad DIHARTO ${ }^{3}$, Imanirrahma SALSABIL ${ }^{4}$
}

Received: July 02, 2020 Revised: July 19, 2020 Accepted: August 10, 2020

\begin{abstract}
The purpose of this study is to examine and analyze the effect of human capital supply chain on the firm performance mediated by innovation culture and innovation process on small- and medium-sized construction enterprises (SMEs) in Indonesia. A survey has been distributed to all construction SMEs that have direct involvement in construction work (contractors and subcontractors). The construction SMEs including medium- and small-scale construction services in three Provinces, namely, the special region of Yogyakarta, East Java, and Central Java. Through purposive sampling technique, primary data is collected by giving a questionnaire to the owner/manager of construction SMEs. The target sample in this study was 200 respondents who have been operating for a minimum of two years. 154 valid questionnaires could be processed. Data analysis uses structural equation modeling with AMOS 24. The results of the study conclude that there is a positive effect on human capital supply chain on firm performance mediated by innovation culture and innovation process, while innovation culture does not affect firm performance. In sum, the innovation culture mediates the relationship between human capital supply chain and firm performance, and the innovation process mediates the relationship between human capital supply chain and firm performance.
\end{abstract}

Keywords: Human Capital Supply Chain, Innovation Culture, Innovation Process, Firm Performance

JEL Classification Code: D8, L1, L2, L22

\section{Introduction}

Indonesia ranks 52 in the world's infrastructure competitiveness 2018. The ranking improved compared to 2010-2013 when the country ranked 70 (Warta Ekonomi, 2020; Berita Satu, 2020). Before COVID-19 was defined as pandemic by WHO on March 13, 2020, the construction industry in the last three years developed rapidly along with the increasing infrastructure development in Indonesia (Ramadian \& Amrina, 2019). It indicates that the construction

${ }^{1}$ First Author and Corresponding Author. Professor, Department of Management, Business and Economics Faculty, Universitas Islam Indonesia [Postal Address: JI. SWK Ringroad Utara Condong Catur, Yogyakarta, 55283, Indonesia] Email: muafi@uii.ac.id

${ }^{2}$ Department of Management, Business and Economic Faculty, Universitas Pembangunan Nasional Veteran Yogyakarta, Indonesia. ${ }^{3}$ Economic and Islamic Business Faculty, Department of Management Institute Agama Islam Negeri Surakarta, Indonesia.

${ }^{4}$ Universitas Gadjah Mada, Yogyakarta, Indonesia.

(c) Copyright: The Author(s)

This is an Open Access article distributed under the terms of the Creative Commons Attribution Non-Commercial License (https://creativecommons.org/licenses/by-nc/4.0/) which permits unrestricted non-commercial use, distribution, and reproduction in any medium, provided the original work is properly cited. business opportunity in Indonesia is actually wide open. The Indonesian government continues to encourage national and private construction service business actors to be actively involved in investment and implementation of infrastructure development. The private sector is expected to get many opportunities from the government so it able to develop rapidly like state-owned enterprises (SOE) construction firms. Unfortunately, the problems faced by construction SMEs are very complicated. Construction SMEs are lacking the opportunity to participate in the construction market because the market is dominated by big-scale contractors and SOEs. It put some construction SMEs out of business.

Actually, before COVID-19 was defined as pandemic, the medium and small-scale construction markets have been relatively undeveloped. One of the reasons is the dominance of SOEs in various projects (Cepagram, 2019). They are not given the opportunity to work, such as concrete portions, large stakes, large or small equipment even though the construction industry is an industry which is quite instrumental in the development of Indonesia's national economy. In 2030, the construction in Indonesia is designed to contribute to the environment in order to create added value in a sustainable manner based on professionalism, 
synergy, and competitiveness (Suraji, 2007), through material savings, waste reduction, and easy maintenance of post-construction buildings (Bria et al., 2017).

Therefore, construction SMEs need to improve their human resource competencies in the construction sector to support the industry growth in the special province of Yogyakarta, East Java, and Central Java. Certified construction workers are needed to work on quality construction projects. In addition, project managers are required to have skills, namely, good leadership, team building, motivation, influence, decision making, political and cultural awareness, negotiation, trust building, conflict management, and coaching (Project Management Institute, 2013; Azis et al., 2016), especially in the supply chain field (Creelman, 2010; Kumar, 2003).

It is important because HR plays an important role in a project's success. HR has a big responsibility to complete the contracted projects. This study focuses on the importance of examining the human capital supply chain aspects owned by construction SMEs to enhance the innovation culture and innovation process so that it will have an impact on firm performance. Reasons that made it very important areas follows.

There is dearth of research that focuses on HC supply chain in Asia (Creelman, 2010; Kumar, 2003), especially associated with innovation culture and innovation process that impact on firm performance. Firms are increasingly aware of the importance of $\mathrm{HC}$ supply chain in inventory management (Kumar, 2003) especially in the current pandemic era. Owners of construction SMEs rarely have good data integration in vendor management systems, applicant tracking systems, human resources information systems and other systems that support firm operations (Creelman, 2010). In this time of COVID-19 era, construction SMEs require the application of very strict supply chain management. Construction SMEs are required to have a HC supply chain looking at various considerations such as management often obtains low quality raw materials at high prices. In addition, management often experiences difficulties when bargaining with suppliers of raw materials and other equipment. The role of HC supply chain is needed in the firm's operational activities, especially in purchasing raw materials, components/parts, and operating equipment which is needed by the firm (Olaore \& Adebisi, 2013; Wisner et al., 2012; Sugandini et al., 2020).

\section{Literature Review}

\subsection{Human Capital (HC) Supply Chain and Innovation Culture}

$\mathrm{HC}$ is a part of the intellectual capital (Yusoff et al., 2019). HC plays an important role in increasing innovation
(Ershova et al., 2018; Fonseca et al., 2018; Lenihan et al., 2017). HC is a strategic intangible asset and has become a more important asset than tangible assets in a knowledgebased economy (Huang \& Kung, 2011). HC is knowledge, employee capability, experience, and ability to implement innovation so that firm goals can be achieved (Huang \& Kung, 2011; Liu et al., 2017). Innovation at the firm level is how the firms effectively manage HR at the team level and individual level to create innovation through the learning process (Aminullah et al., 2017).

Herbig and Dunphy (1998) emphasize the individualistic and collectivist community groups. The greater individual freedom to explore and express opinions exist, the more likely the emergence of new ideas to innovate will emerge. Individualistic societies respect freedom because freedom is needed for creativity. Individualistic societies do not emphasize loyalty, so they gather more information needed for discovery. People in individualistic society prefer to work for small firms rather than large firms. Compensation and recognition needed by the inventor is more directed on single people. Psychological characteristics of independence and achievement to encourage innovation are easier and more commonly found in individualistic societies (Shane, 1992).

Although, firms have begun to understand the importance of having employees who understand inventory management (Kumar, 2003) and implement supply chain management, firms rarely have good data integration systems such as vendor management systems, applicant tracking systems, employee competency in mapping information systems, and other related systems that provide convenience and fluency for company operations. One of the reasons is firms often have poor workforce forecasting, and the recruitment of workers is not well planned because it is conducted at the last minute especially in the case of employees who have expertise in the supply chain (Creelman, 2010). HC supply chain refers to the integration of business planning, strategic workforce planning, staffing and recruitment processes and technology to improve company productivity and profitability. The term HC supply chain emerged in 2009 as one of the total quality management methods, lean management and supplier strategies. It is applied to industries that are expected to increase growth and competitive advantage strategies (Giehl \& Moss, 2009; Muafi, 2020), through innovation culture (Li et al., 2011; Julian \& Wells, 2011; Küçükoğlu \& Pinar, 2018) and innovation process (Perez et al., 2012; Oluwatobi et al., 2016).

Building innovation culture means providing an environment and infrastructure that affect employees to support thoughts and actions needed for innovation (Dobni, 2008). Simpson et al. (2006) believe that firms need to innovate continuously. They must have a common set of 
Muafi MUAFI, Yuni SISWANTI, Awan Kostrad DIHARTO, Imanirrahma SALSABIL /

Journal of Asian Finance, Economics and Business Vol 7 No 9 (2020) 593-602

beliefs and understand how to achieve them. After that, firms must modify their culture to develop an innovative culture. Subramanian (1996) shows that organizational characteristics of innovative firms differ from noninnovative firms. Innovation develops in organization that has a vision to encourage creativity clearly articulated (Villaluz \& Hechanova, 2018). Managers tend to consider the initiation phase (the phase when people's ideas are encouraged to develop in a non-judgmental atmosphere) rather than the innovation implementation phase (Anderson \& King, 1991). There is evidence that shows creativity and innovation with organizational values contribute to the creation of innovation culture (Villaluz \& Hechanova, 2018). The institutional expression of organizational support for innovation provides psychological empowerment for employees, which can serve as an important source of creativity (Gumusluoglu \& Ilsev, 2009). Rothwell and Wissema (1986) explain that the cultural characteristics required an innovating society, such as: willingness to deal with uncertainty and take balanced risks; urgency, timeliness, and readiness to accept change; and dynamic long-term orientation. In a static society that encourages the status quo, innovation will be difficult to occur or only occurs in acute conditions.

According to Hanifah et al. (2019), there are important dimensions in human capital namely, value, uniqueness, creativity, innovativeness, and proactiveness. Hanifah et al. (2019) find that firm must have creative human capital to create innovation culture. Human capital is specific skill and knowledge, which become very valuable in certain firms and cannot be copied by competing firms. Uslu (2015) finds the role of the human resource strategy in creating innovation culture is quite high. Innovation culture is a new ecosystem in business and production. Creating innovation culture requires the role of quality human capital. Culture affects employee behavior which pave the way for innovation acceptance as a significant corporate asset so that employees feel more committed to their organization (Hanifah et al, 2019). Intellectual capital (human capital, social capital, and organizational capital) affects technological innovation. Technological innovation mediates the effect of intellectual capital on innovation business models ( $\mathrm{Li} \&$ yu, 2018). Küçükoğlu and Pinar (2018) find that green organizational culture motivates sustainability and innovation. Human capital supply chain and HR department have significant role in creating organizational culture (Li et al., 2011; Julian \& Wells, 2011; Küçükoğlu \& Pinar, 2018; Giehl \& Moss, 2009; Creelman, 2010; Kumar, 2003). When a firm integrates technology and $\mathrm{HC}$ in a good supply chain, it would be able to have a significant impact on long-term operational sustainability and social responsibility (Sinha \& Goldstein, 2016).
H1. HC supply chain has a positive effect on the innovation culture

\subsection{Human Capital (HC) Supply Chain and Innovation Process}

Developing $\mathrm{HC}$ could improve innovation activities and innovation processes. HC supply chain is the knowledge possessed by people or team in a firm, which is useful for the development of an organization or firm (Perez et al., 2012), especially that related to value chains and inventory management (Giehl \& Moss, 2009; Creelman, 2010; Kumar, 2003).

Ota et al. (2013) state that it is important to manage the innovation process when promoting innovation. Fontana and Musa (2017) define innovation process as an active and conscious process of organizational control and implementation of activities that lead to innovation. They see innovation process as a sequential three-phase process that involves idea making, idea conversion, and diffusion of concepts developed. In the three-phase process, an organization needs to do internal sourcing, cross-unit sourcing, external sourcing, selection, development, and ideas dissemination throughout the firm. In addition, Fontana and Musa (2017) state that innovation process consists of three main steps, namely, the idea of something new (product, service or process), the development of something new, and the commercialization (diffusion) of something new. Adams et al. (2006) present an innovation process framework consisting of seven categories: input, knowledge management, strategy, organization, culture, portfolio management, and commercialization.

Adam et al. (2006) view innovation process as a fourphase process that involves making ideas, selecting ideas, developing ideas, and diffusing ideas. A number of innovation process studies have focused on the firm's internal innovation processes such as research and development, improvement of the production process, and innovation processes. Innovation process arises in social systems, it spreads and establishes in society. According to Oluwatobi et al. (2016), good institution is institution, which supports innovation directly and indirectly through the formation of human capital. Institution and human capital have strong effect on innovation. Wu et al. (2014) find that the basis of technological innovation is human capital. Therefore, human capital is needed to maximize innovation, education, training and health facilities. Jiang et al. (2012) find an important aspect in human capital which can improve creativity innovation such as apply ideas into product, process or procedure which benefit the organization, work team, or individuals.

H2. HC supply chain has a positive effect on the innovation process. 


\subsection{Innovation Culture and Firm Performance}

Culture is inclusive communication system, which unites human biological and technical behavior with verbal and non-verbal expressive behavior system. Culture is the total number of ways of life, such as expected behavior, belief, value, language, and life practice, which are shared by community members. Culture is also defined as pattern of values, traits, or behavior possessed by people in a region (Herbig \& Dunphy, 1998). The relationship between organizational culture and firm performance has become an important topic discussed in the literature. A number of studies have been devoted to examine the role of culture as organizational resources or assets which affect organizational performance (Prajogo \& McDermott, 2011). A recent study (Sorensen, 2002) explains that firms who have cohesive and integrated culture will excel in their performance although they still depend on a relatively stable environment. Innovation culture refers to shared values, beliefs, and shared assumptions of organizational members, which can facilitate the innovation process (Dabić et al., 2018). Innovativeness is usually used to describe a company's tendency to introduce new processes, products, or ideas (Hult et al., 2004). It is a cultural aspect purposive sampling technique, which can affect the firm's tendency to innovate (Kyrgidou \& Spyropoulou, 2013). Recent study about the role of innovation-oriented corporate culture in enhancing corporate innovation shows the ways in which culture positively affects firm performance (Stock et al., 2013; Lee \& Xuan, 2019).

Uzkurt et al. (2013) analyze innovation, organizational culture, and firm performance and find that innovation has a significant effects on firm performance. This finding is supported by Wei et al. (2013) who find that organizational culture improves firm performance. Padilha and Gomes(2016) explain that innovation culture is able to give a greater effect on performance in the innovation process than performance in product innovation. On the other hand, Lee et al. (2016) find that innovation culture improves firm performance both directly and indirectly mediated by ambidexterity. Innovation culture is also important for improving MSME performance (Dabic et al., 2018). Innovation culture is one of the keys for company's success in improving its performance. In addition, Seo et al. (2014) prove that innovation in SC directly affects the SC performance when the level of SC integration of manufacturing firm is quite effective in developing supply chain practices as needed. Cadden et al. (2013) state that organization with high-performance supply chains will have very different cultural profiles in six cultural dimensions (process, employee, open, tight, norm, and market). In contrast, low-performing supply chain organization has profile which is almost identical in six cultures.
H3: Innovation culture has a positive effect on firm performance

\subsection{Innovation Process and Firm Performance}

Innovation can be seen as the extent to which an organization produces, receives, and implements new idea, process, product, or service (Hurley \& Hult, 1998; Damanpour et al., 2009). Kanter (1996) explains innovation as the creation and exploitation of new ideas. Basically, the innovation entrepreneurial process and change contradicts the administrative process to ensure repetitions of the past. Innovation development requires a set of organizational practices and modes which are different from the ongoing management operations where the desire or expectation for change is minimal. Kanter (1996) argues that innovation in technology, administration, product/process, or system tends to have four different characteristics, namely, uncertainty, knowledge-intensive, controversial, and crosses boundaries. There are four main innovation tasks, namely, idea generation and activation of innovation drivers ("entrepreneurs" or "innovators"); coalition building and the acquisition of power are needed to move ideas into reality; idea realization and innovation production, turning ideas into model, product, plans or prototypes which can be used; and transfer or diffusion, model distribution, product commercialization, idea adoption.

Löfsten (2014) analyzes the relationship between innovation and firm performance, which focuses on small and medium-sized companies. Based on literature review, innovation process approach is used as a starting point. In addition, the innovation process approach is divided into two stages - innovative input must be transformed into innovative output (transformation stage or process), and innovative output, can be in the form of actual innovation sales. This innovative output must contribute to the firm's performance, such as turnover, employment growth or profitability. The level of innovative input has a strong positive effect on innovative output. Löfsten (2014) also find that innovative performance contribute to the firm's business performance. The introduction of products to the public also increase repeat purchases on new models and market share (Prajogo $\&$ Sohal, 2003). New products for customers and product lines as well as those utilizing new technology help create new market that result in increase sales and profitability (Lau, 2011). Innovative products which are cost effective increase total market size and profitability by attracting new consumers from untapped market segments ( $\mathrm{Zu}$ et al., 2008; Lee \& Xuan, 2019; Lintukangas et al., 2019). Lee and Nam (2016) state when firm is success in innovating supply chain management and has orientation in supplier strategy, it would have an impact on sustainable performance. 
Muafi MUAFI, Yuni SISWANTI, Awan Kostrad DIHARTO, Imanirrahma SALSABIL /

Journal of Asian Finance, Economics and Business Vol 7 No 9 (2020) 593-602

Innovations in SC management are needed in order to reduce the sustainability risk and provide new ideas in affecting supply markets and sustainable firm performance.

H4. Innovation process has a positive effect on firm performance

H5. HC supply chain has a positive effect on firm performance mediated by the innovation culture

H6. HC supply chain has a positive effect on firm performance mediated by the innovation process

\section{Research Methods}

This study is based on a survey distributed to all construction SMEs that have direct involvement in construction work (contractors and subcontractors). The construction SMEs include medium- and small-scale construction services in three Provinces, namely, the special region of Yogyakarta (DIY), East Java, and Central Java, which handles government, private or self-employed projects. The unit of analysis in this study is the owner and manager of construction SMEs. The target sample in this study, collected by purposive sampling technique, consists of 200 respondents who have been operating for a minimum of two years. Researchers distributed questionnaires when conducting workshops or in-class training organized by state-owned companies. SOEs invited SMEs in the special region of Yogyakarta (DIY), East Java (Surabaya and Malang), and Central Java (Cilacap). The activity conducted as one of the tasks of SOEs involves bridging and providing solutions to problems that occur related to human resources and SMEs performance. This greatly facilitates researchers to conduct data recapitulation and further data analysis. After further analysis, 154 valid questionnaires could be processed and analyzed.

This study uses four variables: human capital supply chain, innovation culture (IA), innovation process (IP), and firm performance (FP). Indicators or questionnaire items refer to:

1. Human capital SC consists of seven items, adopted from Creelman (2010) and Kumar (2003)

2. Innovation Culture (IA) consists of seven items, adopted from Rothwell and Wissema (1986) and Uslu (2015)
3. Innovation process (IP) consists of seven items, adopted from Fontana and Musa (2017) and Damanpour et al. (2009)

4. Firm performance (FP) consists of three items, adopted from Roca-Puig et al. (2011) and Ruíz et al. (2016).

The structural equation model is used with the AMOS 24 statistical technique. The validity and reliability test results conclude that all items and variables are valid and reliable. The normality test results also prove that the data is normally distributed and has no outliers. The model is fit because it fulfilled the Goodness of fit criteria.

\section{Results}

\subsection{Respondents Description}

The majority of respondents have operated for three years $(78 \%)$, are managed by men $(84 \%)$, have an undergraduate education $(81 \%)$, manage construction businesses on a small scale $(87 \%)$ and have permanent employees of 5-10 (79\%).

\subsection{Testing Hypothesis}

The regression weight test results can be seen in Table 1 . Based on Table 1, it can be concluded that $\mathrm{H} 1, \mathrm{H} 2$ and $\mathrm{H} 4$ are supported, while $\mathrm{H} 3$ is rejected.

\subsection{Mediation Test}

The significance of the indirect effect between variables can be seen in Tables 2 and 3. Based on Table 2 and 3, it can be concluded that:

The relationship of HC supply chain and firm performance mediated by innovation culture has significance value of $0.006(<0.05)$, so that the innovation culture mediates the relationship between $\mathrm{HC}$ supply chain and firm performance. The relationship of HC supply chain and firm performance mediated by the innovation process has significance value of $0.005(<0.05)$, so that the Innovation Process mediates the relationship between $\mathrm{HC}$ supply chain and firm performance.

Table 1: Regression Weight Test Result

\begin{tabular}{|l|c|c|c|c|c|c|c|}
\hline & & & Estimate & S.E. & C.R. & P & Hypothesis \\
\hline IA & $<---$ & HC & 1,001 &, 117 & 8,568 & H1: Supported \\
\hline IP & $<---$ & HC & 1,070 &, 096 & 11,160 & *** & H2: Supported \\
\hline BP & $<---$ & IA &, 030 &, 272 &, 110 &, 913 & H3: Rejected \\
\hline BP & $<---$ & IP &, 551 &, 262 & 2,106 & ,035 & H4: Supported \\
\hline
\end{tabular}


Table 2: First Mediation Test Results

\begin{tabular}{|l|c|c|c|}
\hline & HC & IA & BP \\
\hline IA & $\ldots$ & $\ldots$ & $\ldots$ \\
\hline BP &, 006 & $\ldots$ & $\ldots$ \\
\hline
\end{tabular}

Table 3: Second Mediation Test Results

\begin{tabular}{|l|c|c|c|}
\hline & HC & IP & BP \\
\hline IP & $\ldots$ & $\ldots$ & $\ldots$ \\
\hline BP &, 005 & $\ldots$ & $\ldots$ \\
\hline
\end{tabular}

\section{Discussion}

The results prove that $\mathrm{HC}$ supply chain improves firm performance through innovation culture and innovation process. It supports previous studies (e.g., Giehl \& Moss, 2009; Li et al., 2011; Julian \& Wells, 2011; Küçükoğlu \& Pinar, 2018; Küçükoğlu \& Pinar, 2018; Yusoff et al., 2019; 2018). HC supply chain is able to improve firm performance through innovation culture ( $\mathrm{Li}$ et al., 2011; Julian \& Wells, 2011; Küçükoğlu \& Pinar, 2018) and innovation process (Perez et al., 2012; Oluwatobi et al., 2016). Post-pandemic COVID-19 demands firms to innovate. This is important because it can be an indispensable element for organizational sustainability. Innovation culture has become organization's habit and should already be a value passed down from one generation to the next. There are 10 important points in innovation culture, namely: statements related to the vision and mission of innovation, democratic communication, guaranteeing safe space, organization must be flexible, collaboration, boundary spanning, giving incentives, has strong leadership, and has a sustainable orientation. Innovation culture can also be measured by technology updates, information updates, new product development, technology investments, R\&D activities development and must be successful in process and product innovation (Michaelis et al., 2018). Küçükoğlu and Pinar (2018) emphasize that in the long term the green innovation culture can improve business sustainability (business, environment and social) (Yusoff et al., 2018; 2019).

In the COVID-19 pandemic era, firms need to have employees who understand the supply chain. Therefore, firms must have a clear and well-planned recruitment plan in order to help placing employees according to qualifications and other requirements. When HC supply chain is in accordance with the right man at the right place motto, the firm would be able to more easily integrate with the firm's operational strategies and policies. Employees will be very easy and precise in managing the purchasing function to distribute products/services for customers. The HC supply chain must be able to manage various activities in order to obtain raw materials to become products/services in the process become finished products. In the process of products or service delivery to consumers, employees must have skills and expertise, which related to suppliers and distributors, so they get cheap, quality, timely and varied prices. When a firm has a good HC supply chain, the innovation culture and the innovation process will increase and affect the firm's performance.

The firm should also provides a conducive environment and supports infrastructure to support the firm's culture and innovation process. In addition, firms must provide institutional and organizational support so it can provide employees confidence and self-efficacy in making decisions in the pandemic COVID-19 era. It will be able to affect the thoughts and actions needed for employees to innovate on an ongoing basis (Dobni, 2008; Simpson et al., 2006; Villaluz \& Hechanova, 2018; Anderson \& King, 1991), so that employees tend to be creative (Hanifah et al., 2019; Uslu, 2015; Wu et al., 2014). When the firm wants to increase technological innovation, the firm must be committed to provide training, development, and health facility. Education, training, health facility, and other compensation should be optimal to maximize innovation, while adjusting the firm's internal conditions. It is useful to motivate employees in adoption, diffusion and create efficient and effective operationalization work process. Employees can also share knowledge between and across business units which are expected as an effective way to promote collaborative innovation (De Long \& Fahey, 2000; Dombrowski et al., 2007) so firm can implements incentive scheme based on work teams ( Elenkov et al., 2005).

Unfortunately, the innovation culture has no effect on firm performance in this study. It contradicts previous studies (Kyrgidou \& Spyropoulou, 2013; Stock et al., 2013; Uzkurt et al., 2013; Wei et al., 2013). It is possible because the innovation culture in the construction firm emphasizes product innovation more than innovation process. Nowadays, the construction customers see the products rather than the process that has been carried out by the firm. Product innovation is the first stage in the product life-cycle management process. It is also an important stage where the determinant factors for product and production costs are determined so they have a large impact on the firm's competitive position in the future (Löfsten, 2014; Parry et al., 2009). Product innovation includes technical design, R\&D and commercial activities involved in marketing new products (Alegre et al., 2006). Although complex and expensive, product innovation is a major source of firm's future (Brown \& Eisenhardt, 1995). Therefore, the main concern for product innovation managers is managing the complexity of product innovation while ensuring the relationship between product innovation and firm performance (Löfsten, 2014; Aujirpongpan \& Hareebin, 2020). 
Muafi MUAFI, Yuni SISWANTI, Awan Kostrad DIHARTO, Imanirrahma SALSABIL /

Journal of Asian Finance, Economics and Business Vol 7 No 9 (2020) 593-602

\section{Contributions}

The following are managerial contributions of this study.

Although HC supply chain improves firm performance mediated by innovation culture and innovation process, managers must understand the personal characteristics of each employees. Each employee has different characteristics in decision-making ranging from the purchase function to the distribution of products/services to consumers.

When recruiting $\mathrm{HC}$ supply chain, the firm needs to integrate it with business strategy and business planning in order to be compatible with innovation culture and innovation process so the firm's performance will improve.

Construction SMEs should conduct the process of segmentation, targeting and positioning-STP on target, especially in the COVID-19 pandemic era. It is important considering that people currently prioritize food rather than other needs.

In enhancing the innovation culture and innovation process continuously, firms need to conduct training and development for employees, especially at the HC supply chain, so they contribute in improving firm performance.

\section{Limitation and Recommendations}

This study has several limitations. Results show that innovation process does not have a significant effect on firm performance. Therefore, it is necessary to do more in-depth research looking at product innovation so people can see each other's role in making positive contribution to the organization.

The sample size is relatively small and only represents three provinces. It also uses small-scale SMEs. It was feared that findings would not be able to be generalized to the population of construction SMEs in three provinces. Future research should consider medium- and large-scale construction firms, so that differences that have an impact in providing strategic recommendations and policies related to $\mathrm{HC}$ supply chain, innovation culture, and innovation process can be generalized.

There are several variables, which can be considered to affect the innovation culture and innovation process, such as strategic leadership (Elenkov et al., 2005), external and internal environmental (Huang \& Kung, 2011; Sugandini et al., 2019), and information systems (Sugandini et al., 2019). It is necessary to consider other business sustainability indicators, namely, social and environmental performance (Yusoff et al., 2019; 2018; Muafi \& Uyun, 2019; Roespinoedji et al., 2019; Küçükoğlu \& Pinar, 2018)

\section{References}

Adams, R., Bessant, J., \& Phelps, R. (2006). Innovation management measurement: A review. International Journal of Management Reviews, 8(1), 21-47.
Alegre, J., Lapiedra, R., \& Chiva, R. (2006). A measurement scale for product innovation performance. European Journal of Innovation Management, 9(4), 333-346.

Aminullah, E., Hermawati, W., \& Fizzanty, T. (2017). Managing human capital for innovative activities in Indonesian herbal medicine firms. Asian Journal of Technology Innovation, 25(2), 268-287.

Anderson, N., \& King, N. (1991). Managing Innovation in Organisations. Leadership \& Organization Development Journal, 12(4), 17-21.

Aujirpongpan, S., \& Hareebin, Y. (2020). The Effect of Strategic Intuition, Business Analytic, Networking Capabilities and Dynamic Strategy on Innovation Performance: The Empirical Study Thai Processed Food Exporters. Journal of Asian Finance, Economics and Business, 7(1), 259-268. https://doi. org/10.13106/jafeb.2020.vol7.no1.259.

Azis, S., Wahyono, A. H., \& Suyadi. (2016). Analysis of the Effect of Project Manager Competence on Cost Accuracy, Quality and Time. Jurnal Info Manpro, 7(1), 21-33. [Indonesian]

Bria, M., Mauta, M. C., \& Bria, T. A. (2017). The Application of Green Building Council Principles in Terms of Material Aspects and Determination of Selection Criteria for Construction Materials. Jurnal Teknik Sipil, 2(1). Retrieved April 21, 2020 from: http:// jurnal.pnk.ac.id/index.php/jutek/article/view/122. [Indonesian]

Brown, S. L., \& Eisenhardt, K. M. (1995). Product development: past research, present findings, and future directions. The Academy of Management Review, 20(2), 343-378.

Cadden, T., Marshall, D., \& Cao, G. (2013). Opposites attract: organisational culture and supply chain performance. Supply Chain Management: An International Journal, 18(1), 86-103.

Cepagram. (2020). Media Note: Complaints of Construction SMEs over the Domination of BUMN Handling Large Infrastructure Projects. Retrieved April 22, 2020 from: https://cepagram.com/ index.php/2019/06/13/catatan-media-keluhan-ukm-konstruksiatas-dominasi-bumn-tangani-proyek-besar-infrastruktur. [Indonesian]

Creelman, D. (2010). Big Idea: Tim Giehll on Human Capital Supply Chains. Creelman Research, 3(1), 1-3. Available at: https://creelmanresearchlibrary.files.wordpress.com/2010/10/ creelman-2010-vol-3-01-giehll-on-hc-scm.pdf

Dabić, M., Lažnjak, J., Smallbone, D., \& Švarc, J. (2018). Intellectual capital, organisational climate, innovation culture, and SME performance: Evidence from Croatia. Journal of Small Business and Enterprise Development, 1(1), 1-24.

Damanpour, F., Walker, R. M., \& Avellaneda, C. N. (2009). Combinative effects of innovation types and organizational performance: a longitudinal study of service organizations. Journal of Management Studies, 46(4), 650-675.

De Long, D. W., \& Fahey, L. (2000). Diagnosing cultural barriers to knowledge management. Academy of Management Executive, 14(4), 113-127.

Dobni, C. B. (2008). Measuring innovation culture in organizations: The development of a generalized innovation culture construct 
using exploratory factor analysis. European Journal of Innovation Management, 11(4), 539-559.

Dombrowski, C., Kim, J. Y., Desouza, K. C., Braganza, A., Papagari, S., Baloh, P., \& Jha, S. (2007). Elements of innovative cultures. Knowledge and Process Management, 14(3), 190-202.

Elenkov, D. S., Judge, W., \& Wright, P. (2005). Strategic leadership and executive innovation influence: an international multicluster comparative study. Strategic Management Journal, 26(7), 665-682.

Ershova, N., Yutkina, O., Pashkov, A., \& Ivanova, M. (2018). Influence of human capital on the level of innovation activity of an enterprise. MATEC Web of Conferences, 239(2), 1-9.

Fonseca, T., Faria, P., \& Lima, F. (2019). Human capital and innovation: the importance of the optimal organizational task structure. Research Policy, 48(3), 616-627.

Fontana, A., \& Musa, S. (2017). The impact of entrepreneurial leadership on innovation management and its measurement validation. International Journal of Innovation Science, 9(1), 2-19.

Giehl, T., \& Moss, S. (2009). Human Capital Supply Chains. Minneapolis, MN: Hillcrest Publishing Group.

Gumusluoglu, L., \& Ilsev, A. (2009).Transformational leadership and organizational innovation: the roles of internal and external support for innovation. Journal of Product Innovation Management, 26(3), 264-277.

Hanifah, H., Halim, H. A., Ahmad, N. H., \& Zadeh, A. V. (2019). Innovation Culture as a Mediator Between Specific Human Capital and Innovation Performance Among Bumiputera SMEs in Malaysia. Hershey, PA: IGI Global.

Herbig, P., \& Dunphy, S. (1998). Culture and innovation, Cross Cultural Management: An International Journal, 5(4), 13-21.

Huang, C. L., \& Kung, F. H. (2011). Environmental consciousness and intellectual capital management: Evidence from Taiwan's manufacturing industry. Management Decision, 49(9), $1405-1425$.

Hult, G. T. M., Hurley, R. F., \& Knight, G. A. (2004). Innovativeness: its antecedents and impact on business performance. Industrial Marketing Management, 33(5), 429-438.

Hurley, F. B., \& Hult, G. T. M. (1998). Innovation, market orientation and organizational learning: an integration and empirical examination. Journal of Marketing, 62(3), 42-54.

Investor Daily. (20220). PUPR: Opportunities for Construction Business in Indonesia are Open Widely. Retrieved April 22, 2020 from: https://id.beritasatu.com/home/pupr-peluangbisnis-konstruksi-di-indonesia-terbuka-lebar/177977. [Indonesian]

Jiang, J., Wang, S., \& Zhao, S. (2012). Does HRM facilitate employee creativity and organizational innovation? A study of Chinese firms. The International Journal of Human Resource Management, 23(9), 4025-4047.

Julian, F., \& Wells, K. (2011). Greening your organisation: The case of the environment agency. In: D. Bartlett (ed.), Going Green:
The Psychology of Sustainability in the Workplace (pp. 64-85). London, UK: BPS Publications.

Kanter, R. M. (1996). When a Thousand Flowers Bloom: Structural, Collective, and Social Conditions for Innovation in Organizations. In: P. S. Myers (ed.), Knowledge Management and Organisational Design (pp. 93-132). Abingdon, UK: Taylor \& Francis Group.

Küçükoğlu, M. T., \& Pinar, R. I. (2018). The Mediating Role of Green Organizational Culture between Sustainability and Green Innovation: A Research in Turkish Companies. Business and Management Studies: An International Journal, 6, 64-85.

Kumar, S. (2003). Managing human capital supply chain in the Internet era. Industrial Management \& Data Systems, 103(4), 227-237.

Kyrgidou, L. P., \& Spyropoulou, S. (2013). Drivers and performance outcomes of innovativeness: an empirical study. British Journal of Management, 24(3), 281-298.

Lau, A. K. W. (2011). Supplier and customer involvement on new product performance: contextual factors and an empirical test from manufacturer perspective. Industrial Management \& Data Systems, 111(6), 910-942.

Lee, J. W., \& Xuan, Y. (2019). Effects of Technology and Innovation Management and Total Factor Productivity on the Economic Growth of China. Journal of Asian Finance, Economics and Business, 6(2), 63-73. https://doi.org/10.13106/jafeb.2019. vol6.no2.63

Lee, K., Woo, H. G., \& Joshi, K. (2017). Pro-innovation culture, ambidexterity and new product development performance: Polynomial regression and response surface analysis. European Management Journal, 35(2), 249-260.

Lee, T., \& Nam, H. (2016). An Empirical Study on the Impact of Individual and Organizational Supply Chain Orientation on Supply Chain Management. The Asian Journal of Shipping and Logistics, 32(4), 249-255.

Lenihan, H., McGuirk, H., \& Murphy, K. (2019). Driving innovation: Public policy and human capital. Research Policy, 48(9), 1-18.

Li, H., Jin, H., Hua, Y., Kong, C., \& Lin, L. (2011). Green research based on cultural three-hierarchy theory. Journal of Sustainability Development. 4, 196-198

Li, J., \& Yu, D. (2018). The Path to Innovation: The Antecedent Perspective of Intellectual Capital and Organizational Character. Frontiers in Psychology, 9, 2445. doi:10.3389/ fpsyg.2018.02445.

Lintukangas, K., Kähkönen, A.-K., \& Hallikas, J. (2019). The role of supply management innovativeness and supplier orientation in firms' sustainability performance. Journal of Purchasing and Supply Management, 25(4), 100558. https://doi.org/10.1016/j. pursup.2019.100558

Liu, G., Pang, L., \& Kong, D. (2017). Effects of human capital on the relationship between export and firm innovation, Chinese Management Studies, 11(2), 322-345. 
Muafi MUAFI, Yuni SISWANTI, Awan Kostrad DIHARTO, Imanirrahma SALSABIL /

Journal of Asian Finance, Economics and Business Vol 7 No 9 (2020) 593-602

Löfsten, H. (2014). Product innovation processes and the tradeoff between product innovation performance and business performance. European Journal of Innovation Management, $17(1), 61-84$.

Michaelis, T. L., Aladin, R., \& Pollack, J. M. (2018). Innovation culture and the performance of new product launches: A global study. Journal of Business Venturing Insights, 9(C), 116-127.

Muafi, M. (2020). A Nexus among Strategic Orientation, Social Network, Knowledge Sharing, Organizational Innovation, and MSMEs Performance. Journal of Asian Finance, Economics and Business, 7(6), 327-338. https://doi:10.13106/jafeb.2020. vol7.no6.327

Muafi., \& Uyun, Q. (2019).The Influence of Islamic HRM Practices on Organizational Learning and Its Impact on Environmental, Social and Religious Performance. Journal of Entrepreneurship Education, 21(SI), 1-9.

National Construction Services Development Institute. (2007). Indonesian Construction 2030 for the Comfort of the Built Environment. Jakarta, Indonesia: National Construction Services Development Institute. [Indonesian]

Olaore, R. A., \& Adebisi, N. T. (2013). Accounting, purchasing and supply chain management interface. IOSR Journal of Business and Management, 11(2), 80-84.

Oluwatobi, S., David, O. O., Olurinola, I., Alege, P., \& Ogundipe, A. (2016). Human Capital, Institutions and Innovation in SubSaharan. International Journal of Economics and Financial Issues, 6(4), 1507-1514.

Ota, M., Hazama, Y., \& Samson, D. (2013). Japanese innovation processes. International Journal of Operations \& Production Management, 33(3), 275-295.

Padilha, C. K., \& Gomes, G. (2016). Innovation culture and performance in innovation of products and processes: a study in companies of textile industry. RAI Revista de Administração e Inovação, 13(4), 285-294.

Parry, M. E., Song, M., De Weerd-Nederhof, P. C., \& Visscher, K. (2009). The impact of NPD strategy, product strategy, and NPD processes on perceived cycle time. Journal of Product Innovation Management, 26(6), 627-639.

Pérez, R. M. (2012). The relevance of human capital as a driver for innovation. Cuadernos de Economía, 35(98), 68-76.

Prajogo, D. I., \& McDermott, C. M. (2011). The relationship between multidimensional organizational culture and performance. International Journal of Operations \& Production Management, 31(7), 712-735.

Project Management Institute. (2013). A Guide to the Project Management Body of Knowledge ( $5^{\text {th }}$ ed.). Atlanta, GA: PMI Book Service Center.

Ramadian, D., \& Amrina, E. (2019). Supply Chain Management Performance Measurement System in Construction Projects. Jurnal Optimasi Sistem Produksi, 18(1), 75-85. [Indonesian]

Roca-Puig, V., Martın, I. B., \& Cipres, M. S. (2011). Combined Effect of Human Capital, Temporary Employment and
Organizational Size on Firm Performance. Personnel Review, 41(1), 4-22.

Roespinoedji, R., Mohd Saudi, M. H., Hardika, A. L., \& Ashid, A. Z. A. (2019). The Effect of Green Organizational Culture and Green Innovation in influencing Competitive Advantage and Environmental Performance, International Journal of Supply Chain Management, 8(1), 278-286.

Rothwell, R., \& Wissema, H. (1986). Technology, culture and public policy. Technovation, 4(2), 91-115.

Ruíz, M. D., Gutiérrez, J. O., Caro, E. M., \& Navarro, J. G. (2017). Linking an unlearning context with firm performance through human capital. European Research on Management and Business Economics, 23(1), 16-22.

Seo, Y., Dinwoodie, J. \& Kwak, D. (2014). The impact of innovativeness on supply chain performance: is supply chain integration a missing link?. Supply Chain Management, 19(5/6), 733-746.

Shane, S. A. (1992). Why do some societies invent more than others?, Journal of Business Venturing, 7(1), 29-46.

Simpson, P. M., Siguaw, J. A., \& Enz, C. A. (2006). Innovation orientation outcomes: the good and the bad. Journal of Business Research, 59(10-11), 1133-1141.

Sinha, K. K., \& Goldstein, S. M. (2016). Managing Human Capital in Supply Chains: Perspectives on Technological Advancement and Social Responsibility. Doctorate Dissertation. Faculty of the Graduate School, University of Minnesota, Minneapolis, Minnesota.

Sorensen, J. B. (2002). The strength of corporate culture and the reliability of firm performance. Administrative Science Quarterly, 47(1), 70-91.

Stock, R. M., Six, B., \& Zacharias, N. A. (2013). Linking multiple layers of innovation-oriented corporate culture, product program innovativeness, and business performance: a contingency approach. Journal of the Academy of Marketing Science, 41(3), 283-299.

Subramanian, A. (1996). Innovativeness: redefining the concept. Journal of Engineering Technology and Management, 13(3-4), 223-243.

Sugandini, D., Muafi, M., Susilowati, C., Siswanti, Y., \& Syafri, W. (2020). Green Supply Chain Management and Green Marketing Strategy on Green Purchase Intention: SMEs Cases, Journal of Industrial Engineering and Management, 13(1), 79-92

Suraji, A. (2007). Indonesia 2030 construction for the comfort of the built environment: the finest built environment by creating added value in a sustainable manner based on professionalism: synergy, and competitiveness. Jakarta, Indonesia: National Construction Services Development Institute. [Indonesian]

Uslu, T. (2015). Innovation Culture and Strategic Human Resource Management in Public and Private Sector within the Framework of Employee Ownership. Procedia - Social and Behavioral Sciences, 195, 1463-1470.

Uzkurt, C., Kumar, R., Kimzan, H. S., \& Eminog `lu, G. (2013). Role of innovation in the relationship between organizational culture 
and firm performance: A study of the banking sector in Turkey. European Journal of Innovation Management, 16(1), 92-117.

Villaluz, V. C., \& Hechanova, M. R. M. (2018). Ownership and leadership in building an innovation culture. Leadership \& Organization Development Journal, 40(2), 1-14.

Warta Ekonomi. (2020). Kadin: Construction and Infrastructure Industry Competitiveness Increases Significantly. Retrieved April 22, 2020 from: https://www.wartaekonomi.co.id/ read201515/kadin-daya-saing-industri-konstruksi-daninfrastruktur-meningkat-signifikan.html. [Indonesian]

Wei, Y. S., O’Neill, H. M., Lee, R. P., \& Zhou, N. (2013). The Impact of Innovative Culture on Individual Employees: The Moderating Role of Market Information Sharing. Journal of Product Innovation Management, 30(5), 1027-1041. https:// doi.org/10.1111/j.1540-5885.2012.01000.x

Wisner, J. D., Tan, K. C., \& Leong, G. K. (2012). Supply Chain Management: A Balanced Approach (3th ed.). Canada: SouthWestern Cengage Learning.
Wu, D., Wu, Z., Wang, J., \& Zhao, Z. (2014). Inequality, Human Capital, And Innovation: China's Remaining Big Problems. International Journal of Economics and Business Modeling, 5(1), 233-237. Available at: https://bioinfopublication.org/files/ articles/5_1_4_IJEBM.pdf

Yusoff, Y. M., Nejati, M., Kee, D. M. H., \& Amran, A. (2018). Linking Green Human Resource Management Practices to Environmental Performance in Hotel Industry. Global Business Review, 21(3), 1-18.

Yusoff, Y. M., Omar, M. K., Zaman, M. D. K., \& Samad, S. (2019). Do all elements of green intellectual capital contribute toward business sustainability? Evidence from the Malaysian context using the Partial Least Squares method. Journal of Cleaner Production, 234(2019), 626-637. https://doi.org/10.1016/j. jclepro.2019.06.153

Zu, X., Fredendall, L. D., \& Douglas, T. J. (2008). The evolving theory of quality management: The role of Six Sigma. Journal of Operations Management, 26(5), 630-650. 